\title{
Fruit Development of Peach and Japanese Pear as Affected by Destruction of the Embryo and Application of Gibberellins
}

\author{
Shoichi Nakagawa, Isao Kiyokawa, \\ Hiroyuki Matsui and Hiroshi Kurooka \\ College of Agriculture, University of Osaka Prefecture, Sakai, Osaka
}

\begin{abstract}
Summary
The effect of gibberellins on the setting and subsequent growth of peach and Japanese pear fruits has been studied after the embryos were destroyed or the seeds were removed mechanically at different stages of fruit development.

1. In the peach, 14-year-old 'Okubo' trees were used. Among the growth regulators tested, $\mathrm{GA}_{3}$ was only effective on the fruit set and development following destruction of the embryos.

2. In young stages of fruit development, that is 5 and 9 weeks after bloom, the application of $\mathrm{GA}_{3}$ to embryo-killed peach fruit resulted in 8 and 6 per cent set of the mature seedless fruit, respectively. In advanced stages, however, embryo destruction 13 weeks after bloom, with or without application of $\mathrm{GA}_{3}$, resulted in 93 and 85 per cent set of the seedless fruit at maturity.

3. Injury to the fleshy pericarp without destruction of the embryo had little effect on the rate of fruit set when treated 5 and 9 weeks after bloom.

4. Seed removal and gibberellin application to the cut surface of the Japanese pear fruit, cv. 'Shinseiki' were done at five different stages of fruit development. Only $\mathrm{GA}_{4+7}$, applied as a lanolin paste to the cut surface of seed-removed fruit, was effective in sustaining further growth of the fruit when treated 3 and 5 weeks after bloom.

5. At the stage of 7 weeks after bloom, however, not only $\mathrm{GA}_{4+7}$, but also $\mathrm{GA}_{3}$ application began to work effectively to sustain the treated fruit. In late stages subsequent to 9 weeks after bloom, $\mathrm{GA}_{3}$ in lanolin was more effective than $\mathrm{GA}_{4+7}$ on maintaining the seedless fruit.

6. It was also found that a large number of treated fruit were infected with rot and fruit splitting in late stages of fruit development and they abscised before ripening.
\end{abstract}

\section{Introduction}

It is generally well known that fruit growth and development follow the fertilization and seed formation. Moreover, there may be many correlations between fruit growth and seed development; that is, developing seed have a strong controlling effect on fruit growth especially in the early stage. As early as 1936, H. B. Tukey (24) has shown that destruction of the embryo early in Stage II of peach and sour cherry fruit development resulted in an abrupt check of fruit development, with shriveling and abscission. On the other hand, destruction of the embryo late in Stage II or Stage III of pericarp development resulted in Received for publication January 31, 1973. either equal growth rate or an increased growth rate compared to untreated fruit. The same result was obtained by $А$ ввотт(1) through experiments with apple fruit, in which seeds were removed from the fruit at different stages of development. These results mean that the fruit is entirely dependent on the presence of seeds from fruit set to the end of the June drop. $\mathrm{NiTsch}_{\mathrm{T}}(21)$ has also demonstrated the importance of seeds in fruit development by a work with strawberries.

It has been noticed that young seeds are relatively rich sources of growth-promoting substances, such as auxins, gibberellins and cytokinins, and these substances may play an important role in fruit development.

On the other hand, it has been shown that 
parthenocarpic fruit growth can be induced by application of auxins, gibberellins or cytokinins without seed formation. Especially in many fruit trees, gibberellins were the most effective in inducing parthenocarpic fruit growth; $\mathrm{GA}_{3}$ in peach $(6,7,8)$, apricot(6), and $\mathrm{GA}_{4}$ and $\mathrm{GA}_{7}$ in apple $(2,3,17)$ and pear $(17,20)$.

These situations suggest that it may be possible to continue fruit development after destruction of the embryo by the concurrent application of gibberellin during the early stage of fruit development.

The experiment reported herein was conducted to confirm the effect of gibberellins and destruction of the embryo on the development of peach and Japanese pear fruits at different stages of fruit growth.

\section{Materials and Methods}

This study was carried out on 14-year-old peach trees of 'Okubo' cultivar and 15-yearold Japanese pear trees of 'Shinseiki' cultivar growing in the orchard of University of Osaka Prefecture in Sakai, Osaka.

In peaches, the embryos and the seeds in developing fruit were destroyed by using both a needle and a small hand drill following the method of H. B. Tukey(24). In young stages of the developing fruit, 4 or 5 weeks after bloom, it was sufficient to destroy the embryo by piercing the seed with needle through the distal end of the fruit. In advanced stages of the developing fruit, 9 or 10 weeks after bloom, however, it was necessary to drill a hole, $6 \mathrm{~mm}$ in diameter, through the fleshy and stony pericarp into the ovarian cavity, and pick up the broken pieces of seed with narrow tweezers. Immediately after destruction of the embryo or seed, an aqueous solution of $\mathrm{GA}_{3}$ at $500 \mathrm{ppm}$ was injected into the ovarian cavity, and furthermore the solution was applied to the surface of the fruit with a paint brush. $\mathrm{GA}_{4+7}-500 \mathrm{ppm}$, kinetin $-50 \mathrm{ppm}$, IAA-50 ppm and a mixed solution of kinetin$50 \mathrm{ppm}$ and IAA-50 ppm were also used in the experiment of 1968, applying them at the early stage of fruit growth. In advanced stages of fruit development during the growing season of 1969, $\mathrm{GA}_{3}$ prepared as a lanolin paste at $5 \times 10^{-3} \mathrm{M}$ was in jected into the ovarian cavity through the drilled hole and an aqueous solution of $\mathrm{GA}_{3}$ at $1000 \mathrm{ppm}$ was also applied to the surface of the fruit. Fruit samples of uniform size were selected and thinned so as to have one fruit on a mediumsized bearing shoot. A hundred fruit were used in each treatment. The number of fruit growing on the tree in each treated plot was counted at one or two weeks intervals during the current season. Fruit sizes were determined on several tagged fruit on a tree at one or two weeks intervals.

In the case of the Japanese pear, the upper end of the fruit was cut off and the seeds were picked up from the fruit with tweezers, and then either a lanolin preparation of $\mathrm{GA}_{3}$ or $\mathrm{GA}_{4+7}$ at $5 \times 10^{-3} \mathrm{M}$, or lanolin alone as a check, was applied on the cut surface of the seedless fruit. Fruit samples of uniform size were carefully selected, and a hundred fruit samples were used in each treatment. The number of dropped fruit in each treatment was checked and recorded and fruit sizes were also determined at weekly intervals during the growing season of 1970 .

\section{Results}

\section{Peach}

Changes in fruit set percentages of 'Okubo' peach for each treatment in 1968 are shown in Fig. 1. In this case, the embryo was destroyed 30 days after bloom and various

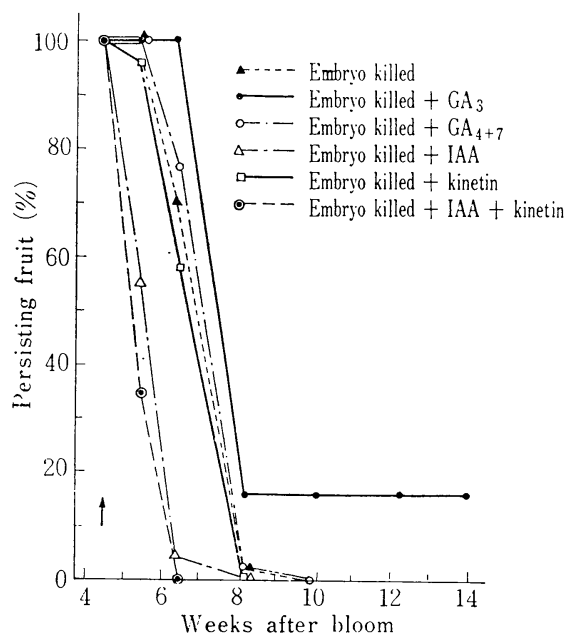

Fig. 1. Changes in the percentage of fruit set as affected by application of various growth regulators to the embryo-killed Okuko peach fruit. 

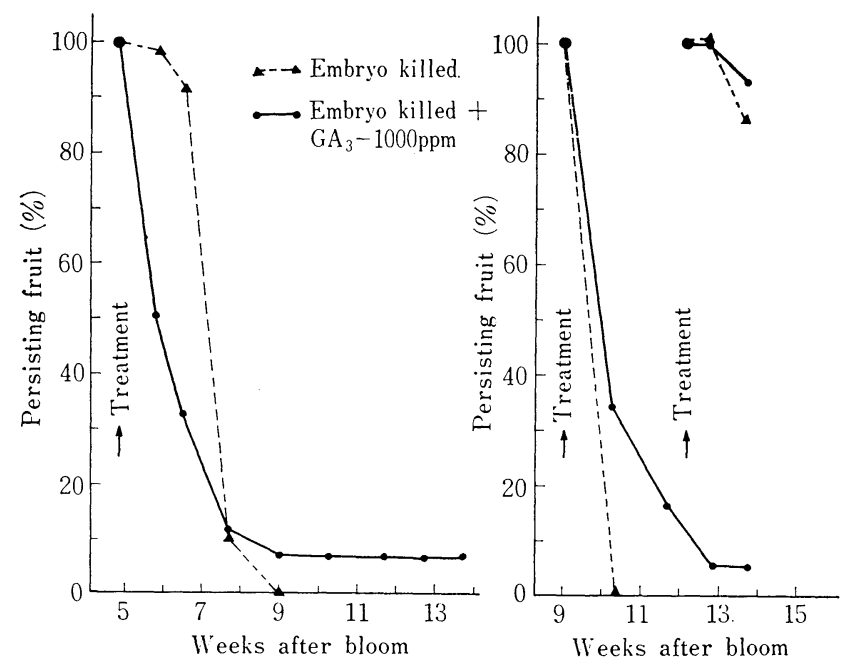

Fig. 2. Changes in the percentage of fruit set as affected by $\mathrm{GA}_{3}$ application to the embryo-killed Okubo peach fruit at three different stages of fruit development.
In 1969, $\mathrm{GA}_{3}$ prepared as a lanolin paste at $5 \times 10^{-3} \mathrm{M}$ and $1000 \mathrm{ppm}$ solution were applied to the peach fruit immediately after the destruction of the embryo at three different stages of fruit development, that is, 9 and 13 weeks after bloom. The results are shown in Fig. 2. The application of $\mathrm{GA}_{3}-1000 \mathrm{ppm}$ to the embryo-killed peach fruit at 5 and 9 weeks after bloom resulted in 8 and 6 per cent set of the mature seedless fruit, respectively. Other embryo-killed fruit, without application of $\mathrm{GA}_{3}$, abscised within 4 weeks after the treatment. In advanced stages, the treatment of embryo destruction did not prevent the subsequent fruit growth. That is, the treatment of embryo destruction at 13 weeks growth regulators, such as $\mathrm{GA}_{3}-500 \mathrm{ppm}$, $\mathrm{GA}_{4+7}-500 \mathrm{ppm}$, IAA-50 ppm, kinetin-50 p pm and a mixed solution of kinetin-50 ppm and IAA-50 ppm, were applied separately to the peach fruit. Among the growth regulators tested, only $\mathrm{GA}_{3}$ was effective for fruit set following the destruction of the embryo, and a 16 per cent set of normal mature seedless fruit was obtained. Other growth regulators did not work effectively to get the fruit growing and all of the treated fruit abscised within 40 days after the treatment. after bloom, with or without application of $\mathrm{GA}_{3}$, resulted in 93 and 85 per cent set of the seedless fruit at maturity. However, in 'KoyoHakuto' peach, fruit set and development could not be obtained by the embryo-destruction and $\mathrm{GA}_{3}$-treatment at young stages of fruit development. In this cultivar, it is difficult to induce parthenocarpy by $\mathrm{GA}_{3}$-application.

Changes in growth curves of 'Okubo' peach fruit as affected by both treatments of embryo destruction and $\mathrm{GA}_{3}$-application are shown in Fig. 3, compared with growth curves of normal
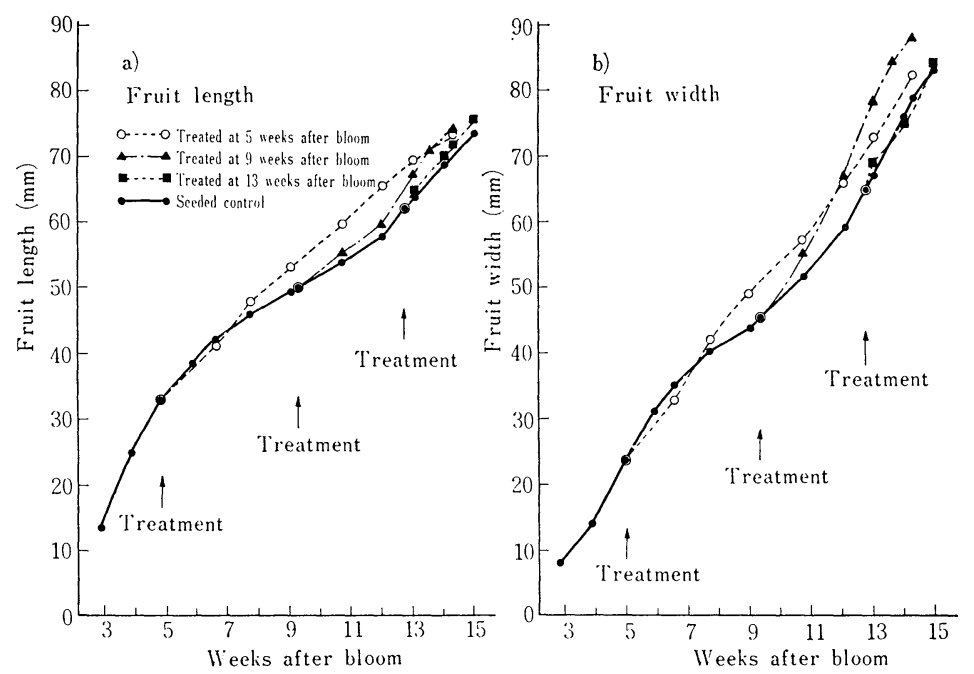

Fig. 3. Changes in growth curves of Okubo peach fruit as affected by $\mathrm{GA}_{3}(1000 \mathrm{ppm})$ application to the embryo-killed fruit at three diffrerent stages of development as: compared with normal seeded fruit. 


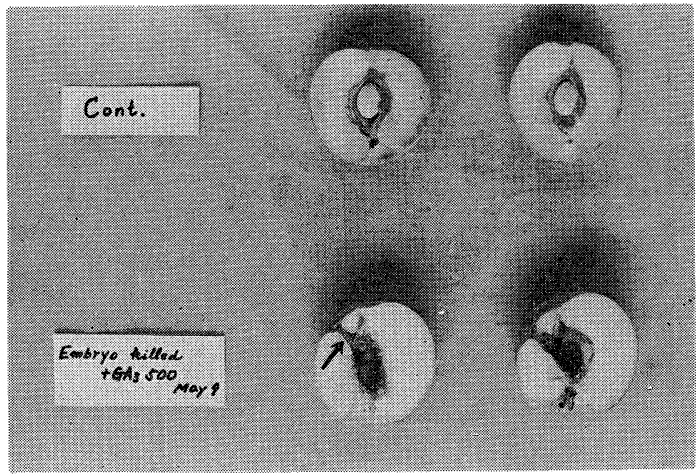

(A)

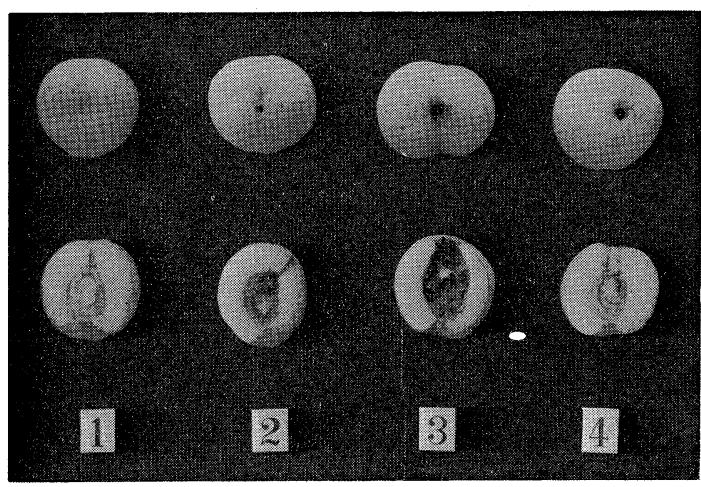

(B)

Fig. 4. Photographs illustrating seeded and seedless Okubo peach fruit treated with $\mathrm{GA}_{3}$ immediately after embryo destruction.

A. 1968. Upper: Seeded control.

Lower : $\mathrm{GA}_{3}-500 \mathrm{ppm}$ application 30 days after bloom.

Arrow showing the position of the needle injected.

B. 1969. 1. Seeded control 2. $\mathrm{GA}_{3}-1000$ ppm application 5 weeks after bloom 3. $\mathrm{GA}_{3}-1000$ application 9 weeks after bloom 4. $\mathrm{GA}_{3}-1000 \mathrm{ppm}$ application 13 weeks after bloom

seeded fruit. Figs. 3 (a) and 3 (b) show the growth curves of fruit length and width, respectively. The treatment of gibberellin application following the embryo destruction at 5 and 9 weeks after bloom increased growth rate of the peach fruit both in fruit length and width. Especially, the fruit treated at 5 weeks after bloom did not show the suspended growth in stage II. The increase in fruit growth was remarkable in fruit width of the peach which was treated at 9 weeks after bloom and final size at maturity was also greater than the seeded control. On the other

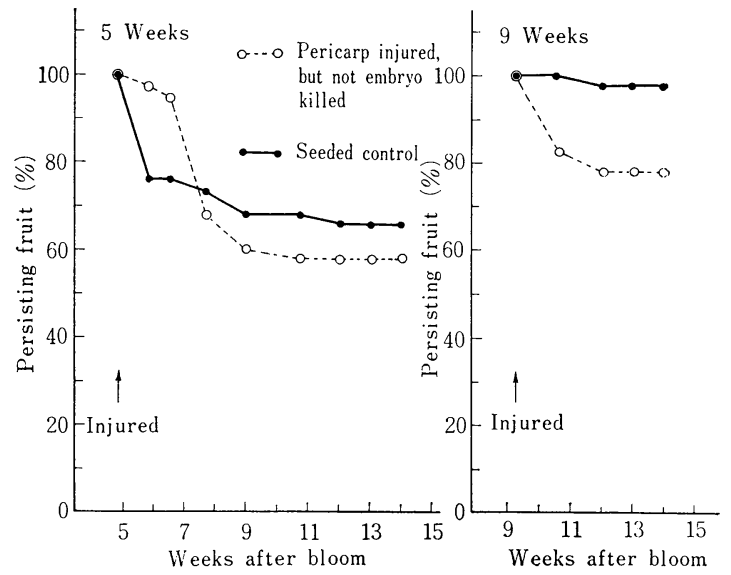

Fig. 5. Changes in the percentage of persisting fruit as affected by injury treated only to the flesh pericarps of Okubo peaches without destruction of the embryo.

hand, there was little difference in fruit size at maturity between the fruit treated at 5 and at 13 weeks after bloom and the seeded control fruit (Fig. 4).

It was also found that fruit maturity was hastened by the treatments of embryo destruction and gibberellin application by about 1 week or so. Especially, the treatment at Stage III (13 weeks after bloom) was more effective to hastened the fruit maturity.

Drillings only in the fleshy pericarps were made as checks to see the effect of injury on the fleshy pericarp incidental to the destruction of the embryo on the fruit set and growth of 'Okubo' peach. As shown in Fig. 5 , injury in fleshy pericarp without destruction of the embryo had little effects on the rate of fruit set, when the treatments were done at 5 and 9 weeks after bloom. It was also found that final sizes of the fruit with injured fleshy pericarps were comparable to those of normal seeded fruit at maturity.

\section{Japanese pear}

The treatments of seed removal and gibberellin application to the cut surface of the Japanese pear fruit, cv. 'Shinseiki', were done at five different stages of fruit development during the current season of 1970 , that is, $3,5,7,9$ and 11 weeks after bloom.

Changes in the percentage of persisting fruit after the treatment are shown in Fig. 6. Only $\mathrm{GA}_{4+7}$ applied as a lanolin paste to the 


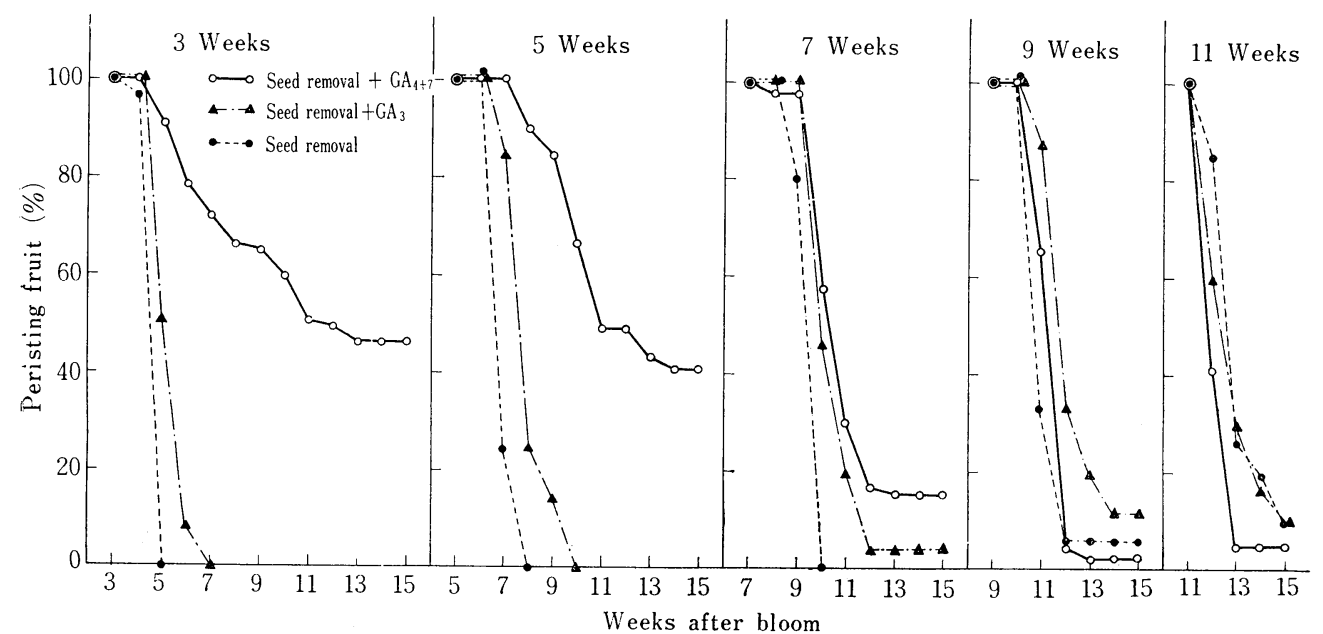

Fig. 6. Changes in the percentage of fruit set as affected by gibberellin application to the seed-removed Japanese pear fruit (CV. Shinseiki) at different stages of development.

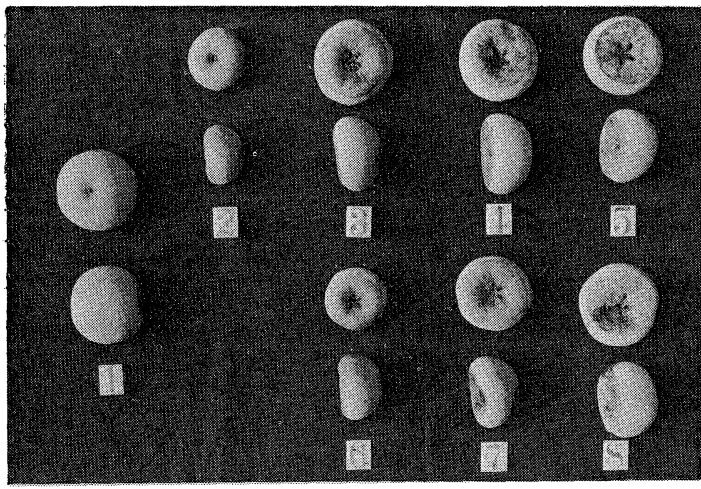

(A)

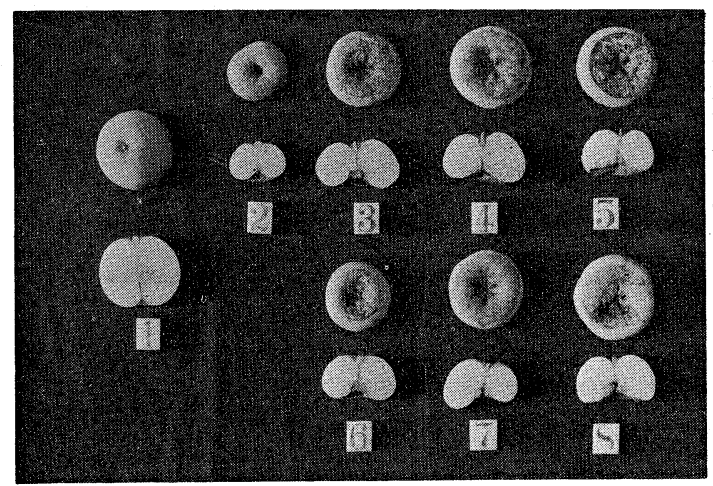

(B)

Fig. 7. Photographs illustrating seeded and seedless Japanese pear fruit (CV. Shinseiki) treated with $\mathrm{GA}_{4+7}$ or $\mathrm{GA}_{3}$ at 4 different stages of fruit development immediately after the seed removal.

1. Seeded control 2 5. $\mathrm{GA}_{4+7}$ application $3,5,7$ and 9 weeks after bloom

$6 \sim 8$. $\mathrm{GA}_{3}$ application 5,7 and 9 weeks after bloom

(The photographs (A) and (B) were taken from different angles.)

cut surface of seed-removed fruit was effective in preventing abscission of the fruit and for their further growth, when the treatments were done at 3 and 5 weeks after bloom, and 46 and 41 per cent set of mature seedless and depressed fruit were obtained, respectively (Fig. 7). All other fruit treated with $\mathrm{GA}_{3}$ in lanolin preparation or lanolin alone to the cut surface of seed-romoved fruit abscised within 4 weeks after the treatments. At the stage of 7 weeks after bloom, however, not only $\mathrm{GA}_{4+7}$ but also $\mathrm{GA}_{3}$ application to the cut surface of seed-removed fruit began to work effectively to maintain the treated fruit, although $\mathrm{GA}_{3}$ was inferior to $\mathrm{GA}_{4+7}$. Other seed-removed fruit, treated with lanolin alone dropped off within 3 weeks. In late stages subsequent to 9 weeks after bloom, $\mathrm{GA}_{3}$ in lanolin was more effective than $\mathrm{GA}_{4+7}$ in preventing abscission of the seed-removed fruit, and furthermore, 5 to 10 per cent of mature seedless fruit was obtained by the treatment of lanolin without gibberellin. In all of the treatments conducted at the late stages of fruit development, however, percentages of fruit set were comparatively low, because there were difficulties involving infection with rot and fruit splitting. 


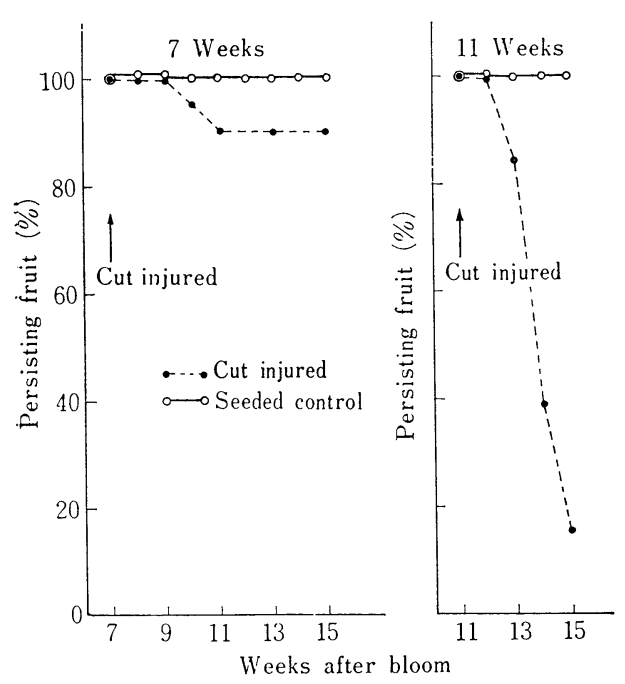

Fig. 8. Changes in the percentage of persisting fruit as affected by cut injury only to the fleshy pericarps of Shinseiki pears without removing the seeds.

In order to see the effect of cut injury to the fruit cortex incidental to removal of the seeds, cutting treatment in the cortex without removing the seeds, were done at 7 and 11 weeks after bloom. As shown in Fig. 8, injury by cutting at 7 weeks after bloom did not affect much fruit set and further fruit growth, showing about 10 per cent fruit drop at maturity. However, when the cut treatment was done at 11 weeks after bloom, the number of fruit persisting decrease remarkably day by day, and only 15 per cent of the injured fruit remained on the tree at maturity. This was because of infection with rot and fruit splitting.

Growth curves of 'Shinseiki' pear fruit showing the transverse diameter as affected by seed removal and gibberellin application at different stages of fruit development are shown in Fig. 9. The treatment of $\mathrm{GA}_{4+7}$ at 3 and 5 weeks after bloom did not prevent further growth, showing almost the same growth in fruit width as the seeded one. It is very interesting to note that the cut surface of the fruit treated with $\mathrm{GA}_{4+7}$ was recovered with wound tissue within a week or so, and in this wound tissue, chlorophyll was formed within 4 weeks after the treatment. Conversely, treatment with $\mathrm{GA}_{3}$ did not work effectively to maintain and develop the fruit, and they abscised 4 weeks after the treatment. At the stage of 7 weeks after bloom, not only $\mathrm{GA}_{4+7}$ but also $\mathrm{GA}_{3}$ application to the cut surface of seed-removed fruit was effective in making seedless fruit. The growth rate of the fruit treated with $\mathrm{GA}_{4+7}$ was greater than that of the seedied control and of the fruit treated with $\mathrm{GA}_{3}$. However, it was also found that severe fruit splitting later occurred more often in the fruit treated with $\mathrm{GA}_{4+7}$, than with $\mathrm{GA}_{3}$. Subsequent to 9 weeks after bloom, the seed-removal treatment did not much effect fruit growth whether $\mathrm{GA}_{4+7}$ or $\mathrm{GA}_{3}$ was applied to the cut surface of the fruit or not. However, at these late stages of fruit development, a large number of the treated fruit were infected with rot and they abscised before ripening.

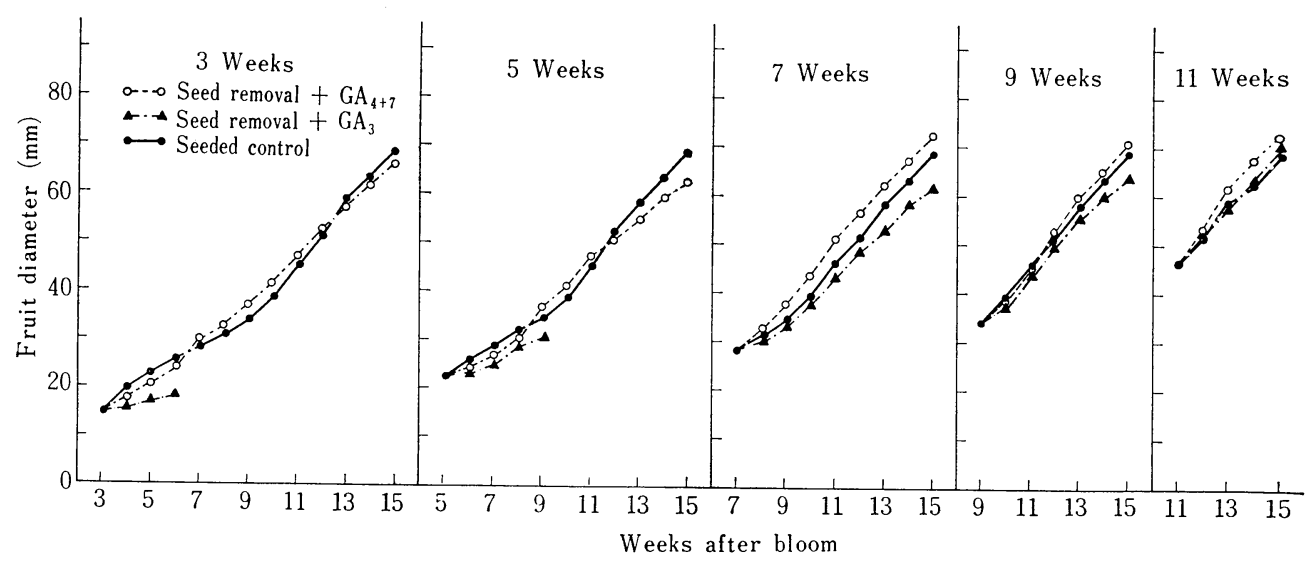

Fig. 9. Changes in growth curves of Japanese pear fruit (CV. Shinseiki) as affected by gibberellin application to the seed-removed fruit at different stages of development as compared to normal seeded fruit. 


\section{Discussion}

The results presented here demonstrated the fact that peach and pear fruits are capable of growing and maturing when the embryo is destroyed, or the seeds are removed mechanically, and exogenous gibberellins are applied simultaneously during the young stage of fruit growth. In other words, it was found that gibberellins could substitute for the role of seeds in fruit development.

$\operatorname{Nitsch}(21)$ has shown with the strawberry that total removal of the achenes completely stops further growth of the fleshy part, and fertilized achenes can be replaced by synthetic growth regulators $(\beta-\mathrm{NOA}$ and $\beta$-IBA) in their action upon the growth of the receptacle. Recently, Crane and $\operatorname{Nelson}(9)$ reported that apricot fruit in which the embryos were killed by application of $\mathrm{MH}$ as early in their development as the latter part of Stage I did not abscise, and grew practically as much as fruit containing seeds. They stated in their discussion that the cause of the difference between the results of Tukey(24), who worked with peaches in which the embryos were killed mechanically, and their results with apricots in which the seeds were aborted chemically, may be explained by competition between fruits and vegetative organs for metabolites. They also supposed that in the case of Tukey's experiments, the source of hormones was eliminated by the destruction of the embryo, and the fruit dropped because they could no longer compete with vegetative growing points for metabolites.

Anyway, as shown in the present study, the resumption of fruit growth by gibberellin application in peach and pear indicates that metabolites continuously flow into the fruit and normal growth takes place in spite of embryo destruction. It may be possible to make an assumption that exogenously applied gibberellins could create a new sink in the fruit in place of the fertilized seeds. However, it is still unknown whether gibberellins are working directly to prevent abscission and to continue the development of the embryo-killed fruit, or if gibberellins are indirectly effective to produce auxin and cytokinin in the fruit.

The presence of gibberellin-like substances in the peach seeds has been indicated by several workers (JACKSON(13), OGAWA(22,23)), however, no isolation of $\mathrm{GA}_{3}$ from the peach seed has: yet been performed, except in the work of Mathur et al.(19) in which endogenous $\mathrm{GA}_{3}$, and $\mathrm{GA}_{7}$ were found in the peach seeds during stratification at $0^{\circ} \mathrm{C}$. YAMAGUCH et al.(25) isolated water soluble gibberellin from immature seeds of the peach and identified it as $\mathrm{GA}_{32}$.

As for the induction of parthenocarpy in the peach, $\mathrm{C}_{\mathrm{RANE}}$ et al. $(6,7,8)$ have demonstrated that $\mathrm{GA}_{3}$ could induce parthenocarpic fruit in some cultivars of the peach. KiуокаwA. and NAKAgAwA(15) also reported that in some Japanese cultivars of the peach, $\mathrm{GA}_{3}$ was only effective in inducing parthenocarpy, but $\mathrm{GA}_{4+\tau}$ does not work at all. They also pointed out the specificity among peach cultivars of $\mathrm{GA}_{3}-$ induced parthenocarpy. Recently, Coombe(5) found that $\mathrm{GA}_{32}$ purified from apricot seed is very active in promoting the growth of unpollinated apricot ovaries with a normal ratio. of length to diameter. From the results of the present experiment (see Fig. 2), fruit set of the peach was as low as below 10 per cent when the treatments were done at 5 and 9 . weeks after bloom. These facts suggest that fruit set and development is not only dependent. on $\mathrm{GA}_{3}$, but also on $\mathrm{GA}_{32}$ or other growth regulators.

In the apple seed, Dennis and $\operatorname{Nitsch}(10)$ have demonstrated the presence of a mixture of $\mathrm{GA}_{4}$ and $\mathrm{GA}_{7}$ in the seeds of 'Golden Delicious' apple. Luckwill et al.(18) also confirmed the presence of $\mathrm{GA}_{4}$ and $\mathrm{GA}_{7}$ in developing. apple seeds by using thin layer and gas-liquid chromatographies. However, no evidence has. been obtained so far concerning the presence of gibberellin in seeds of Japanese pear. Luckwill(17) reported the first induction of parthenocarpy with gibberellin in apple and pear. In 1963, BuKovac(2) demonstrated that $\mathrm{GA}_{4}$ was more effective than $\mathrm{GA}_{3}$ to induce parthenocarpy in 'Sops-of-Wine' and 'Wealthy' apples. Nakagawa et al.(20) also documented parthenocarpic and asymmetric growth induced by $\mathrm{GA}_{4}$ and $\mathrm{GA}_{7}$ in 'Wealthy' apple and Japanese pear cv. 'Shinseiki'. These findings suggest that the seeds of apple and pear are rich source of gibberellins and exogenously' 
applied $\mathrm{GA}_{4}$ and $\mathrm{GA}_{7}$ could induce parthenocarpy and further seedless fruit growth. The results presented here have further confirmed these suggestions.

It was also interesting to note that in early stage of fruit development $\mathrm{GA}_{4+7}$ was more effective than $\mathrm{GA}_{3}$, but in late stages $\mathrm{GA}_{4+7}$ was inferior to $\mathrm{GA}_{3}$ in preventing abscission and maintaining further growth of the seedremoved pear fruit. HAYASHI et al.(12) isolated $\mathrm{GA}_{3}$ from frost induced parthenocarpic young apple fruit and they suggested that fruit tissues other than seeds may participate in the biosynthesis of gibberellins. These facts suggest that different gibberellins are needed for fruit growth in different stages of fruit development.

In Japanese pear $\mathrm{GA}_{4}$ and $\mathrm{GA}_{7}$ may be required for fruit growth in early stages and $\mathrm{GA}_{3}$ in late stages, and $\mathrm{GA}_{4}$ and $\mathrm{GA}_{7}$ in seeds or fruit tissues may be changeable to $\mathrm{GA}_{3}$ during the fruit development.

Bukovac(2) has pointed out that gibberellins may have no direct effect on fruit abscission and may play a specific role in the growth of fruit. He also suggested that auxins, giberellins, cytokinins and perhaps other unidentified growth factors may be responsible for fruit setting and fruit growth. Recently, Котов and $\operatorname{Schwabe}(16)$ have shown that it is possible to obtain normal sized parthenocarpic fruit in 'Cox's Orange Pippin' apples if mixtures of an indole type auxin, gibberellin and synthetic cytokinin are applied simultaneously.

Further investigations are needed to confirm the relationships between the role of seeds and the role of gibberellins or other growth regulators for fruit development, especially concerning cultivar specificity.

\section{Acknowledgement}

We are indebted to Prof. and Dr. Bruce B. Stowe, Yale university, for his kind criticism of the manuscript.

\section{Literature Cited}

1. Aввотт, D. L. 1954. Rep. Agri. Hort. Res. Sta. Bristol : 53 (Cited from 'Hormonal aspects of fruit development in higher plant' by L.C. LUCKWILL, 1957).

2. BUKOVAC, M. J. 1963. Induction of parthenocarpic growth of apple fruits with gibberellin $\mathrm{A}_{3}$ and $\mathrm{A}_{4}$. Bot. Gaz., 124(3), 191-195.
3. tive potency of gibberellins in inducing parthenocarpic growth in Malus sylvestris. Experientia, $23: 865$.

4. —, and 1968. Gibberellininduced asymmetric growth of apple fruits. Hortscience, 3(3) : 172-173.

5. COOMBE, B. G. 1971. $\mathrm{GA}_{32}$ : A polar gibbere1lin with biological potency. Science, 172 : $856-857$.

6. Crane, J. C., P. E. PRimer, and R. C. CAMpbell. 1960. Gibberellin induced parthenocarpy in Prunus. Proc. Amer. Soc. Hort. Sci., 75 : 129 137.

7. - C. A. Rebeiz, and R. C. CAMpbell. 1961. Gibberellin-induced parthenocarpy in the J.H. Hale peach and the probable cause of "Button" production. Proc. Amer. Soc. Hort. Sci., $78: 111-118$.

8. 1963. Parthenocarpic peach development as influenced by time of gibberellin application. Proc. Amer. Soc. Hort. Sci., 83 : $240-247$.

9. —, and M. M. Nelson. 1970. Apricot fruit growth and abscission as affected by Maleic Hydrazid-induced seed absorption. J. Amer. Soc. Hort. Sci., 95 (3) : 302-306.

10. Dennis, F. G. Jr., and J. P. NitsCh. 1966. Identification of gibberellin $A_{4}$ and $A_{7}$ in immature apple seeds. Nature, $211: 781-782$.

11. 1967. Apple fruit set: Evidence for a specific role of seeds. Science, 156 : $71-73$.

12. Hayashi, F., R. Naito, M. J. Bukovac, and H. M. SELL. 1968. Occurrence of gibberellin $\mathrm{A}_{3}$ in parthenocarpic apple fruit. Plant physiol., $43: 448-450$.

13. JACKSON, D. I. 1967. Gibberellin-like substances in peach tissue : Separation by thinlayer electrophoresis and chromatography. Planta, 74 : 324-329.

14. 1958. Gibberellin and the growth of peach and apricot fruits. Aust. J. Biol. Sci., $21: 209-215$.

15. KIYOKAWA, I., and S. NAKAGAWA. 1972. Parthenocarpic fruit growth and development of the peach as influenced by gibberellin application. J. Jap. Soc. Hort. Sci., 41(2) : 133143.

16. Котов, M. A., and W. W. Shw ABE. 1971. Induction of parthenocarpic fruit in Cox's Orange Pippin apple. J. Hort. Sci., 46 : 89-93.

17. LUCKWILL, L. C. 1960. The effect of gibberellic acid on fruit set in apple and pear. Ann. Rep. Long Ashton Agr. and Hort. Res. Sta., 1959 : $59-64$. 
18. —, P. WEAVER, and J. MACMILLAN. 1969. Gibberellins and other growth hormones in apple seeds. J. Hort. Sci., $44: 413-424$.

19. Mathur, D. D., G. A. COUvillon, H. M. Vines, and C. H. HENDERSHOTT. 1971. Stratification effects on endogenous gibberellic acid in peach seeds. Hortscience, 6(6) : 538-539.

20. NAKAGAwA, S., M. J. BukobaC, N. HiRATA, and H. KUROOKA. 1968. Morphological studies of gibberellin-induced parthenocarpic and asymmetric growth in apple and Japanese pear fruits. J. Jap. Soc. Hort. Sci., 37(1) : 919.

21. NitsCH, J.P. 1950. Growth and morphogenesis of the strawberry as related to auxin. Amer. J. Bot., 37 : 211-215.

22. OGAWA, Y. 1965. Changes in the content of gibberellin-like substances in the seeds of Prunus persica. Bot. Mag. Tokyo, 78 : 412416.

23. 1966. Ethyl acetate-soluble and "water soluble" gibberellin-like substances in the seeds of Pharbitis nil, Lupinus lutens, and Prunus persica. Bot. Mag. Tokyo, 79 : 69-76.

24. TUKEY, H. B. 1936. Development of cherry and peach fruits as affected by destruction of the embryo. Bot. Gaz., $98: 1-24$.

25. YAMAGUCHI, I., T. YOKOTA, N. MUROFUSHI, Y.OGAWA, and N.TAKAHASHI. 1970. Isolation of water-soluble gibberellin from immature seeds of Prunus persica. Agr. Biol. Chem., 34 : 1439.

\title{
モモおよび日本ナシの果実発育におよぼす 胚の破壊とジベレリン処理の影響
}

\author{
中川昌一・清川薰雄・松井弘之 - 黒岡 浩 \\ (大阪府立大学農学部)
}

\begin{abstract}
摘
モモ拈よび日本ナシを用いて，果実発育のいろいろな 時期に人為的に胚拉よび種子を破壊し, その後の着果に 特よぼすジベレリソの効果について調査した.

1. モモ (14 年生大久保) では, 胚の破壊後の着果, 発育には $\mathrm{GA}_{3}$ のみが有効であり， $\mathrm{GA}_{4+7}$ ならびに他の 生長調節物質処理扣よび無処理では処理後 4 週間以内に すべて落果した.

2. 果実発育の初期, すなわち開花後 5 扣よび 9 週間 めの泼の破壊扣よび $\mathrm{GA}_{3}$ 処理で, それぞれ 8 就よび 6\%の着果をえ, その後も正常に発育して成熟に達した. しかし, 果実発育の後期, すなわち開花後 13 週間めの 処理では, $\mathrm{GA}_{3}$ 処理の有無にかかわらず, 85〜93\% が 着果し, 成熟が促進された。
\end{abstract}

\section{要}

3. 胚を破壞せず，果肉のみに傷を与兄た場合には， 着果, 発育はほとんど影響されなかつた。

4. 日本ナシ（新世紀）では，果実発育の 5 段階にお いて果頂部を切断して種子を取り除き,さらに切断面に ラノリン加用のジベレリンを施用したところ, 開花後 3 および 5 週間めでは $\mathrm{GA}_{4+7}$ のみが種子を除去した後の 着果拈よび果実発育に効果があつた.

5. しかし, 開花後 7 週間以後では $\mathrm{GA}_{4+7}$ のみなら ず, $\mathrm{GA}_{3}$ も着果に効果があり, 開花後 9 週間以後の処 理では $\mathrm{GA}_{4+7}$ より $\mathrm{GA}_{3}$ のほうが着果に対して効果が大 きかつた。

6. 発育の後期に括壮る処理では, ナシ果実に裂果や 腐敗が多く発生し, 成熟前に落果するものが多かつた。 